\title{
LABORATORY MEASUREMENTS OF EVAPORATION RATE OF DROPLETS AT LOW RELATIVE WIND SPEED
}

\author{
M. E. Teske, H. W. Thistle, C. M. Riley, A. J. Hewitt
}

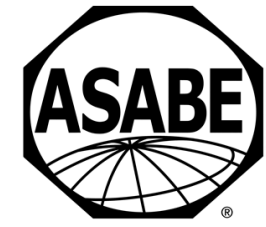

\begin{abstract}
This article summarizes further experimental data collected regarding the evaporation rate of isolated water droplets and strengthens previously published results regarding droplet evaporation at low relative wind speeds. The results suggest that as the Reynolds number (based on the relative velocity between the droplet and ambient air) decreases toward zero, the droplet evaporation rate falls to one-half its value. Because released spray droplets quickly attain near-background velocities, this result implies that evaporation continues for longer times than historically thought but at a lower rate. Additional measurements on traditional fluids (WHO, deionized, distilled, and tap water) provide a consistent benchmark with which to compare evaporation rates.
\end{abstract}

Keywords. AGDISP, Droplets, Evaporation rate, Reynolds number.

$\mathrm{T}$ The evaporation rate of aerially released spray material was quantified from first principles by Fuchs (1959) and later included in an equation, proposed by Trayford and Welch (1977), that solves for the decrease in droplet size over time due to evaporation. This model addresses an important consequence of aerially spraying, i.e., evaporation of the spray carrier, and is included in the deposition model AGDISP (Teske et al., 2003b). In an earlier collection of droplet data, Riley et al. (1995) observed that the droplet evaporation rate decreased to one-half its value as wind speed over the stationary droplet was reduced to zero. This behavior was previously confirmed for WHO water (342 ppm hardness water meeting the standards set in WHO, 2011) by Teske et al. (1998) and more recently by Teske et al. (2017). These previous results are presented in figure 1, where the evaporation rate is plotted as a function of Reynolds number: $\operatorname{Re}=D U / v$, where $D$ is the droplet diameter $(\mu \mathrm{m}), U$ is the relative velocity $\left(\mathrm{m} \mathrm{s}^{-1}\right)$, and $v$ is the kinematic viscosity $\left(\mathrm{m}^{2} \mathrm{~s}^{-1}\right)$. As may be seen from figure 1 , the evaporation rate $(\lambda)$ levels off above Re greater than 7.0

(c) (1) $\Theta$ The authors have paid for open access for this article. This NonCommercial-NoDerivatives 4.0 International License https://creativecommons.org/licenses/by-nc-nd/4.0/

Submitted for review in December 2017 as manuscript number MS 12743; approved for publication by the Machinery Systems Community of ASABE in March 2017.

Mention of company or trade names is for description only and does not imply endorsement by the USDA. The USDA is an equal opportunity provider and employer.

The authors are Milton E. Teske, Senior Associate, Continuum Dynamics, Inc., Ewing, New Jersey; Harold W. Thistle, Program Manager, USDA Forest Service, Morgantown, West Virginia; Christopher M. Riley, Specialist in Pesticide Risk Reduction, Agrifor Biotechnical Services Ltd., Fredericton, New Brunswick, Canada; Andrew J. Hewitt, Professor (Research), University of Queensland, Gatton Campus, Queensland, Australia, and University of Nebraska, West Central Research and Extension Center, North Platte, Nebraska. Corresponding author: Milton E. Teske, Continuum Dynamics, Inc., 34 Lexington Ave., Ewing, NJ 08616; phone: 609-538-0444; e-mail: milt@continuum-dynamics.com. (to $\lambda_{o}$ ) and appears to decrease to as low as 0.4 of $\lambda_{o}$ as $\mathrm{Re}$ approaches zero. This behavior is confirmed with an addi-

tional dataset in an effort to resolve the behavior of droplet evaporation at low relative wind speed.

\section{APPROACH}

The computer model AGDISP includes an isolated droplet evaporation model for evaporating released spray material in aerial application predictions. AGDISP incorporates a Lagrangian solution scheme to track the release of droplets into the atmosphere. The evaporation of the volatile portion of the released spray is seen as critical to the prediction of ground deposition and off-target drift (Bird et al., 2002). Droplet evaporation is based on the diameter-squared law, in which the time rate of change of droplet diameter is given as:

$$
\frac{d D}{d t}=-\frac{D}{2 \tau_{e}\left(1-\frac{t}{\tau_{e}}\right)}
$$

where $t$ is the time (s), and $\tau_{e}$ is the evaporation time scale of the droplet (s), defined by:



Figure 1. Evaporation rate behavior comparison for WHO water at low Reynolds numbers. 


$$
\tau_{e}=\frac{2 D_{O}{ }^{2}}{\lambda \Delta \Theta S h}
$$

where $D_{O}$ is the initial droplet diameter $(\mu \mathrm{m}), \lambda$ is the evaporation rate $\left(\mu \mathrm{m}^{2} \mathrm{~s}^{-1}{ }^{\circ} \mathrm{C}^{-1}\right), \Delta \Theta$ is the wet bulb temperature depression $\left({ }^{\circ} \mathrm{C}\right)$, and $\mathrm{Sh}$ is the Sherwood number: $\mathrm{Sh}=$ $2\left(1+0.27 \mathrm{Re}^{1 / 2}\right)$. Equation 1 can be integrated to give:

$$
1-\frac{D^{2}}{D_{O}{ }^{2}}=\frac{t}{\tau_{e}}
$$

The present effort exercises this simple modeling approach to determine $\lambda$ at low relative wind speeds.

\section{METHOD}

Evaporation data for WHO water droplets were generated using a test system developed and described in much greater detail by Riley et al. (1995). Droplet generation, capture, and image processing were carried out within a modified Conviron E7 environmental chamber (Controlled Environments Ltd., Winnipeg, Manitoba, Canada). Droplets were generated in still air using an ultrasonic atomizer fed from a syringe pump. Droplet evaporation took place in a steady airstream at a preselected air velocity, temperature, and relative humidity. Test results relied on interpretation of time-lapse photographs of individual droplets generated, captured, and suspended on strands of spruce budworm webbing wound across a wire support structure positioned within the field of view of a microscope equipped with a video camera. The field of view was approximately $6.0 \mathrm{~mm} \times 4.6 \mathrm{~mm}$. A series of images were captured over the lifetime of the droplets in view of the camera. Image capture and analysis were performed with Optimas software (Bioscan Inc., Edmonds,

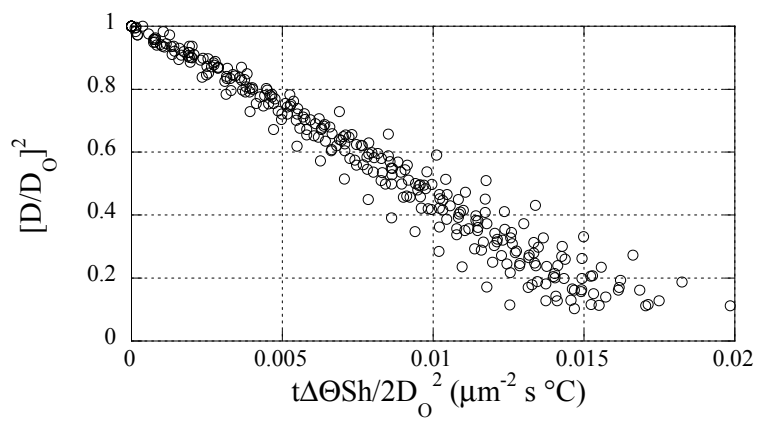

(a)

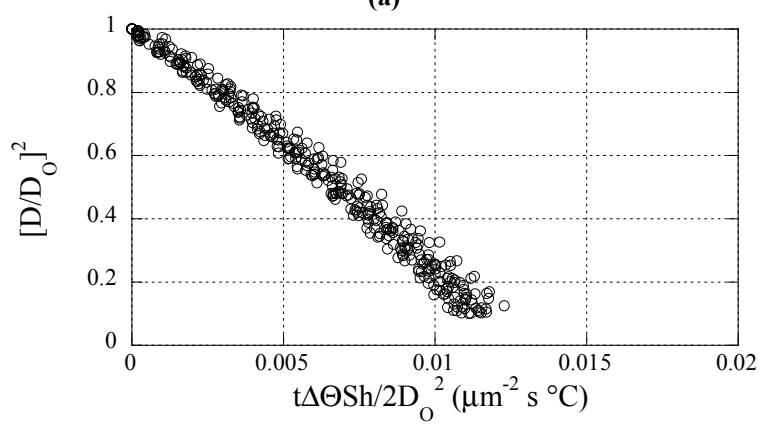

(c)
Wash.). Measurements of droplet size were generally terminated when droplet diameters evaporated down to 0.3 times their initial values.

\section{RESULTS}

A total of 75 individual droplets were identified in 60 tests, several with two or three independent droplets tracked, as summarized in table 1. Initial droplet diameters ranged from 103.2 to $271.8 \mu \mathrm{m}$. These data were examined by applying equation 3 to each set of data (each droplet time history), using equation 2 to recover $\lambda$. Droplet size behavior is plotted in figure 2, with one figure for each speed range (for clarity). The average slope of the combined data for $\operatorname{Re}>3.5$ (when relative wind speeds are sufficiently larger than zero) gives an evaporation rate of $\lambda_{O}=80.61 \mu \mathrm{m}^{2} \mathrm{~s}^{-1}{ }^{\circ} \mathrm{C}^{-1}$. This result is higher than the evaporation rates previously determined for WHO water by Teske et al. $(2016,2017)$ of $\lambda_{O}=62.40$ and $63.66 \mu \mathrm{m}^{2} \mathrm{~s}^{-1}$ ${ }^{\circ} \mathrm{C}^{-1}$, respectively. The reason for this difference is unknown, as there were no changes made to the test system, and the calibration was well within specifications. Figure 3 composites the behavior of the 75 droplets as a function of Re. The decrease in evaporation rate for Reynolds numbers approaching zero is apparent in this figure. It may be seen in both figures 1 and 3 that the value of $\lambda / \lambda_{O}$ often decreases below a value of 1.0 for $\operatorname{Re}<5.0$. Quantification of this behavior is discussed later in this article.

Table 1. Average test conditions for the WHO water tests.

\begin{tabular}{cccccc}
\hline $\begin{array}{c}\text { Tunnel } \\
\begin{array}{c}\text { Speed } \\
\left(\mathrm{m} \mathrm{s}^{-1}\right)\end{array}\end{array}$ & $\begin{array}{c}\text { Reynolds } \\
\text { Number }\end{array}$ & $\begin{array}{c}\text { No. of } \\
\text { Tests }\end{array}$ & $\begin{array}{c}\text { No. of } \\
\text { Droplets }\end{array}$ & $\begin{array}{c}\text { Temp. } \\
\left({ }^{\circ} \mathrm{C}\right)\end{array}$ & $\begin{array}{c}\text { RH } \\
(\%)\end{array}$ \\
\hline 0.0 & 0.0 & 10 & 14 & 21.8 & 29.0 \\
0.14 & 0.64 to 1.70 & 15 & 17 & 21.4 & 30.0 \\
0.20 & 1.89 to 3.37 & 18 & 25 & 21.5 & 29.8 \\
0.27 & 3.50 to 5.49 & 17 & 19 & 21.4 & 30.1 \\
\hline
\end{tabular}

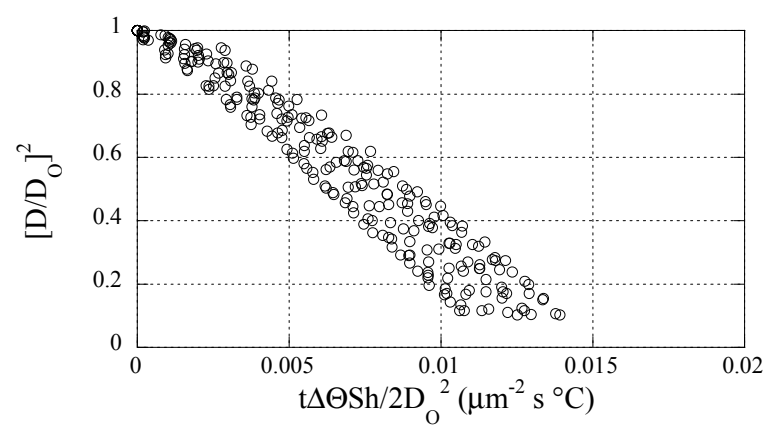

(b)

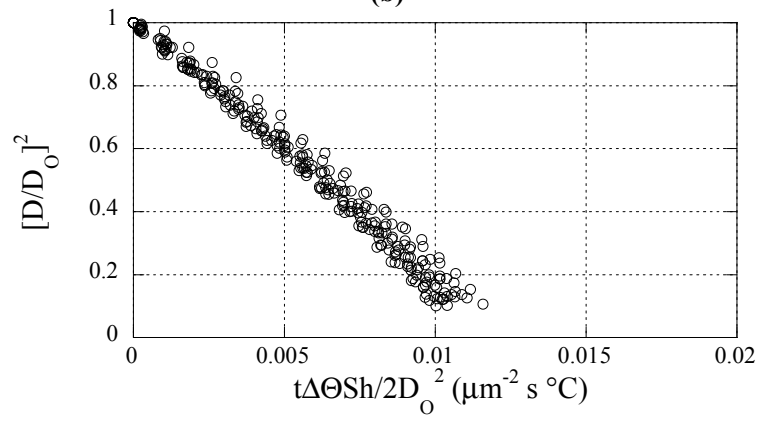

(d)

Figure 2. Evaporation time histories of applicable WHO water droplets with (a) 14 droplets with $\operatorname{Re}=0.0$, (b) 17 droplets with $0.0<\operatorname{Re}<1.75$, (c) 25 droplets with $1.75<\operatorname{Re}<3.5$, and (d) 19 droplets with $\operatorname{Re}>3.5$. 


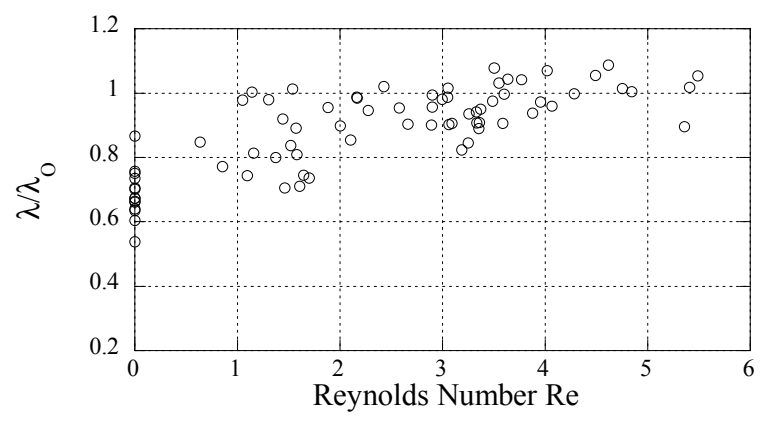

Figure 3. Evaporation rate behavior of all WHO water droplets shown in figure 2.

Table 2. Average test conditions for the sensitivity tests.

\begin{tabular}{cccccc}
\hline $\begin{array}{c}\text { Tunnel } \\
\begin{array}{c}\text { Speed } \\
\left(\mathrm{m} \mathrm{s}^{-1}\right)\end{array}\end{array}$ & $\begin{array}{c}\text { No. of } \\
\text { Tests }\end{array}$ & $\begin{array}{c}\text { No. of } \\
\text { Droplets }\end{array}$ & $\begin{array}{c}\text { Temp. } \\
\left({ }^{\circ} \mathrm{C}\right)\end{array}$ & $\begin{array}{c}\text { RH } \\
(\%)\end{array}$ & Test Substance \\
\hline 0.36 & 4 & 7 & 21.4 & 30.0 & Deionized water \\
0.43 & 3 & 6 & 21.8 & 30.5 & Distilled water \\
0.37 & 4 & 8 & 21.7 & 30.0 & Tap water \\
\hline
\end{tabular}

\section{SENSITIVITY RESUlTS}

To study the sensitivity of droplet evaporation with respect to water quality, a series of tests were also conducted with deionized water (water that has had almost all of its mineral ions removed), distilled water (water boiled and then collected and condensed), and tap water (115 ppm hardness water from Fredericton, New Brunswick, as found on the website www.aquatell.ca). These tests followed the experimental procedure discussed in the Method section and are summarized in table 2 . Their droplet size behavior is shown in figure 4, resulting in evaporation rates of $\lambda_{O}=64.29$, 61.31, and $61.94 \mu \mathrm{m}^{2} \mathrm{~s}^{-1}{ }^{\circ} \mathrm{C}^{-1}$, respectively. Initial droplet diameters varied from 142.3 to $278.6 \mu \mathrm{m}$. Reynolds numbers varied from 3.44 to 7.83 .

\section{DisCUSSION}

Figure 1 suggests, as expected, a rapid increase in the evaporation rate from its quiescent value to nonzero wind speed. The revised evaporation rate correction builds on these data (from Teske et al., 1998, 2017), combined with the present data (shown in fig. 3) to develop the cubic curve fit shown in figure 5 :

$$
\begin{aligned}
\lambda / \lambda_{O}= & 0.5+0.27812(\mathrm{Re})-0.051249\left(\mathrm{Re}^{2}\right) \\
& +0.0031249\left(\mathrm{Re}^{3}\right), \operatorname{Re} \leq 5.0
\end{aligned}
$$

Equation 4 provides an expression that quantifies the behavior of the evaporation rate of WHO water as the relative wind speed between the droplet and its ambient environment nears zero (near-quiescent conditions typical of the aerial release of pesticides once the droplets interact with the ambient air). The model at $\operatorname{Re}=0.0\left(\lambda / \lambda_{O}=0.5\right)$ is based on an observation made by Riley et al. (1995) and confirmatory data on the evaporation rate of dilute and non-dilute clouds of tetrahydronaphthalin $\left(\mathrm{C}_{10} \mathrm{H}_{12}\right)$ droplets released into a quiescent chamber by Wong and Chang (1992).

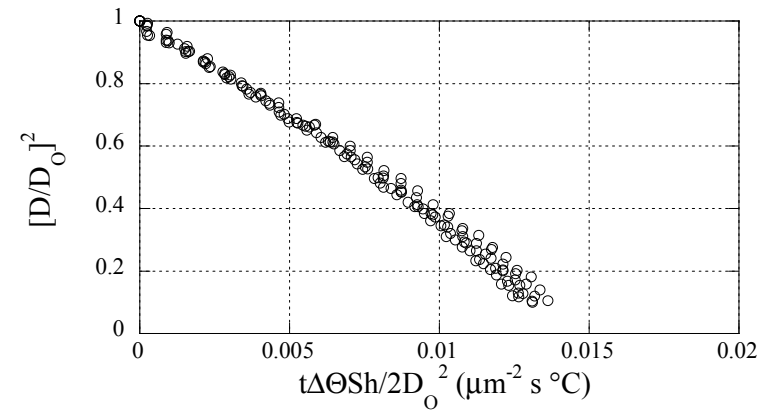

(a)

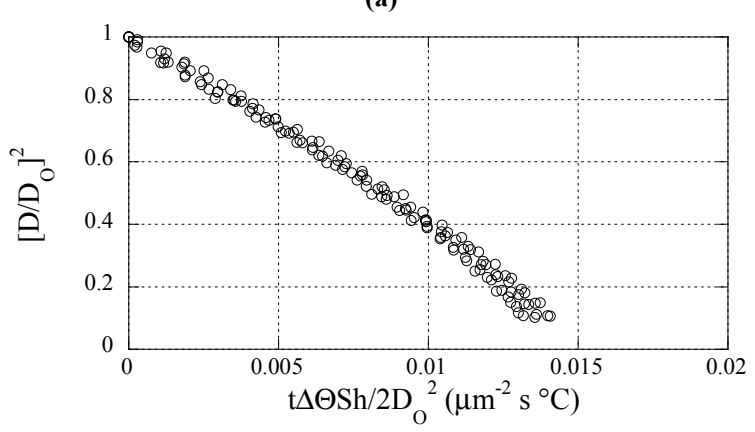

(b)

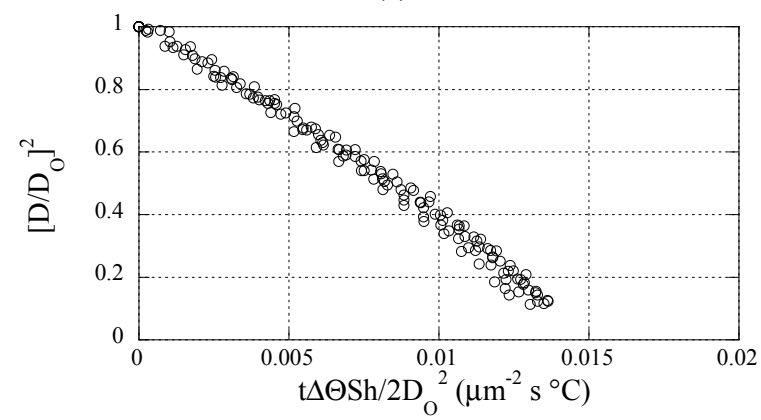

(c)

Figure 4. Evaporation time histories of applicable water droplets with (a) seven droplets of deionized water, (b) six droplets of distilled water, and (c) eight droplets of Fredericton, New Brunswick, tap water.

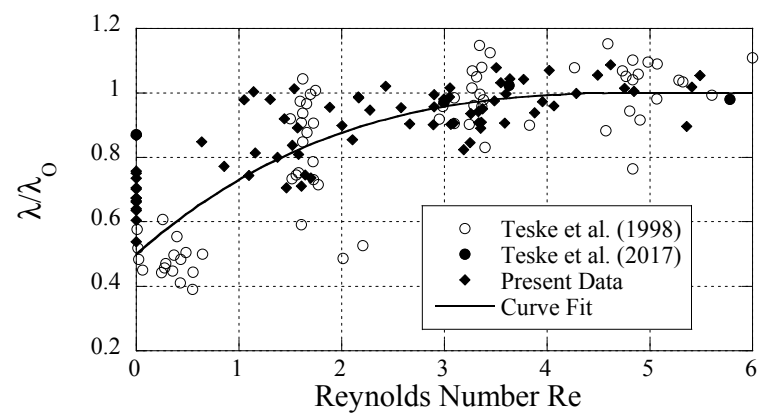

Figure 5. Cubic curve fit to low relative wind speeds for three data sets: Teske et al. $(1998,2017)$ and present data as shown.

The evaporation rate across the four types of water examined in this article, along with data from other published sources, provide the results presented in table 3 . 
Table 3. Measured or inferred evaporation rates of water.

\begin{tabular}{|c|c|c|c|}
\hline Substance & Technique & $\begin{array}{c}\text { Evaporation Rate } \\
\left(\mu \mathrm{m}^{2} \mathrm{~s}^{-1}{ }^{\circ} \mathrm{C}^{-1}\right)\end{array}$ & Source \\
\hline \multirow[t]{5}{*}{ WHO water } & Placed on $<100 \mu \mathrm{m}$ diameter glass filament & 71.07 & Gay and Segers (1994) \\
\hline & Placed on 2 to $4 \mu \mathrm{m}$ diameter webbing & 62.0 & Riley et al. (1995) \\
\hline & Placed on 2 to $4 \mu \mathrm{m}$ diameter webbing & 62.40 & Teske et al. (2016) \\
\hline & Placed on 2 to $4 \mu \mathrm{m}$ diameter webbing & 63.66 & Teske et al. (2017) \\
\hline & Placed on 2 to $4 \mu \mathrm{m}$ diameter webbing & 80.61 & Present data \\
\hline \multirow[t]{3}{*}{ Deionized water } & Placed on 2 to $4 \mu \mathrm{m}$ diameter webbing & 70.24 & Riley et al. (1995) \\
\hline & Placed on 2 to $4 \mu \mathrm{m}$ diameter webbing & 85.53 & Riley (2008) \\
\hline & Placed on 2 to $4 \mu \mathrm{m}$ diameter webbing & 64.29 & Present data \\
\hline Deionized and distilled water & Freely floating at terminal velocity & 76.42 & Beard and Pruppacher (1971) \\
\hline \multirow[t]{2}{*}{ Distilled water } & Placed on $85 \mu \mathrm{m}$ diameter wire & 124.47 & Luo et al. (1994) \\
\hline & Placed on 2 to $4 \mu \mathrm{m}$ diameter webbing & 61.31 & Present data \\
\hline \multirow[t]{6}{*}{ Tap water } & Freely falling & 90.25 & Kinzer and Gunn (1951) \\
\hline & Derived from basic heat transfer properties & 84.76 & Fuchs (1959) \\
\hline & Freely floating at terminal velocity & 82.77 & Dennison and Wedding (1984) \\
\hline & Held at tip of $0.18 \mathrm{~mm}$ syringe & 114.47 & Kincaid and Longley (1989) \\
\hline & Held at tip of $0.18 \mathrm{~mm}$ syringe & 90.39 & Kincaid (1989) \\
\hline & Placed on 2 to $4 \mu \mathrm{m}$ diameter webbing & 61.94 & Present data \\
\hline
\end{tabular}

Several observations are offered:

- The evaporation rate of WHO water droplets appears most definable, with values between 62.0 and $80.61 \mu \mathrm{m}^{2} \mathrm{~s}^{-1}{ }^{\circ} \mathrm{C}^{-1}$.

- The evaporation rate of deionized and distilled water varies across a wide range.

- The evaporation rate of tap water varies across a wide range as well.

The techniques used to hold an evaporating droplet and record the droplet size as evaporation takes place may have interfered with previous droplet evaporation experiments. The average evaporation rate for droplets identified as placed on 2 to $4 \mu \mathrm{m}$ diameter webbing is $68.00 \mu \mathrm{m}^{2} \mathrm{~s}^{-1}{ }^{\circ} \mathrm{C}^{-1}$, while all other tests (droplets placed on a glass filament, an $85 \mathrm{~mm}$ diameter wire, held at the tip of a $0.18 \mathrm{~mm}$ syringe, or freely floating at terminal velocity) give $91.82 \mu \mathrm{m}^{2} \mathrm{~s}^{-1}$ ${ }^{\circ} \mathrm{C}^{-1}$.

The effects of a change in the evaporation rate as the Reynolds number approaches zero can be seen by running several AGDISP calculations. These predictions were undertaken with model default inputs but with a release height of $5 \mathrm{~m}$ and no canopy. The settings were: Air Tractor 401, temperature of $18.33^{\circ} \mathrm{C}$, relative humidity of $50 \%$, and crosswind speed of $2.24 \mathrm{~m} \mathrm{~s}^{-1}$. The results are presented in figure 6, which plots the behavior of evaporation as a function of evaporation rate. Overall, the use of equation 4 reduces the fraction of carrier evaporated by an average of $8.4 \%$.

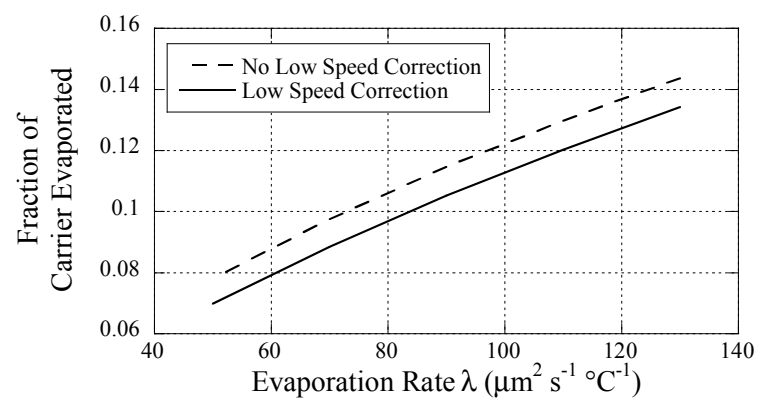

Figure 6. Evaporation of carrier as a function of evaporation rate: "no low speed correction" sets the evaporation rate equal to its $\lambda o$ value for all Reynolds numbers; "low speed correction" imposes equation 4 for Reynolds numbers less than 5.0.
Correspondingly, the use of the minimum and maximum evaporation rates $\left(61.31\right.$ and $124.47 \mu^{2} \mathrm{~s}^{-1}{ }^{\circ} \mathrm{C}^{-1}$, respectively, from table 3) suggests that the fraction of carrier evaporated may vary by as much as $62 \%$ and that increased evaporation decreases ground deposition (Teske et al., 2003a). It is therefore important to model aerial application with an evaporation rate appropriate for the spray material released.

\section{Conclusions}

This article first examined WHO water droplet evaporation as the relative wind speed between the droplet and ambient air is reduced to zero, resulting in a formula for evaporation rate dependent on Reynolds numbers of 5.0 and smaller. This article also examined the evaporation rates of deionized water, distilled water, and tap water, resulting in average evaporation rates for each material (folding in evaporation rates determined from available literature) and an average evaporation rate comparison between measurement techniques.

\section{REFERENCES}

Beard, K. V., \& Pruppacher, H. R. (1971). A wind tunnel investigation of the rate of evaporation of small water drops falling at terminal velocity in air. J. Atmos. Sci., 28(8), 14551464. https://doi.org/10.1175/15200469(1971)028<1455:awtiot $>2.0 . c 0 ; 2$

Bird, S. L., Perry, S. G., Ray, S. L., \& Teske, M. E. (2002). Evaluation of the AgDISP aerial spray algorithms in the AgDRIFT model. Environ. Toxicol. Chem., 21(3), 672-681. https://doi.org/10.1002/etc.5620210328

Dennison, R. S., \& Wedding, J. B. (1984). Determination of evaporation rates of pesticide droplets. Report No. 84342801. Missoula, MT: USDA Forest Service, Equipment Development Center.

Fuchs, N. A. (1959). Evaporation and droplet growth in gaseous media. Elmsford, NY: Pergamon.

Gay, B. P., \& Segers, D. P. (1994). Specialized laboratory support (task TA-31) droplet evaporation. Report No. FPM 94-9. Davis, CA: USDA Forest Service, Forest Pest Management.

Kincaid, D. C. (1989). Volumetric water drop evaporation 
measurement. Trans. ASAE, 32(3), 925-927.

https://doi.org/10.13031/2013.31092

Kincaid, D. C., \& Longley, T. S. (1989). A water droplet evaporation and temperature model. Trans. ASAE, 32(2), 457463. https://doi.org/10.13031/2013.31026

Kinzer, G. D., \& Gunn, R. (1951). The evaporation, temperature and thermal relaxation-time of freely falling waterdrops. $J$. Meteorol., 8(2), 71-83. https://doi.org/10.1175/15200469(1951)008<0071:tetatr $>2.0 . c 0 ; 2$

Luo, Y., Miller, D. R., Yang, X., McManus, M. L., \& Krider, H. M. (1994). Characteristics of evaporation from water-based bacterial pesticide droplets. Trans. ASAE, 37(5), 1473-1479. https://doi.org/10.13031/2013.28230

Riley, C. M. (2008). Spray droplet evaporation studies under low humidity conditions. RPC Report No. OAS/08/01. Fredericton, New Brunswick, Canada: Research and Productivity Counci.

Riley, C. M., Sears, I. I., Picot, J. J., \& Chapman, T. J. (1995). Description and validation of a test system to investigate the evaporation of spray droplets. In F. R. Hall, P. D. Berger, \& H. M. Collins (Eds.), Pesticide formulations and application systems (Vol. 14, pp. 225-236). Philadelphia, PA: ASTM Int. https://doi.org/10.1520/STP13011S

Teske, M. E., Hermansky, C. G., \& Riley, C. M. (1998).

Evaporation rates of agricultural spray material at low relative wind speeds. Atomiz. Sprays, 8(4), 471-478.

https://doi.org/10.1615/AtomizSpr.v8.i4.70
Teske, M. E., Kaufman, A. E., Thistle, H. W., Hewitt, A. J., \& Valcore, D. L. (2003a). Droplet evaporation corrections for aerial spray drift modeling I: Theoretical considerations. Atomiz. Sprays, 13(2-3), 243-250. https://doi.org/10.1615/AtomizSpr.v13.i23.50

Teske, M. E., Thistle, H. W., \& Ice, G. G. (2003b). Technical advances in modeling aerially applied sprays. Trans. ASAE, 46(4), 985-996. https://doi.org/10.13031/2013.13955

Teske, M. E., Thistle, H. W., Riley, C. M., \& Hewitt, A. J. (2016). Initial laboratory measurements of the evaporation rate of droplets inside a spray cloud. Trans. ASABE, 59(2), 487-493. https://doi.org/10.13031/trans.59.11543

Teske, M. E., Thistle, H. W., Riley, C. M., \& Hewitt, A. J. (2017). Laboratory measurements on the sensitivity of evaporation rate of droplets inside a spray cloud. Trans. ASABE, 60(2), 361-366. https://doi.org/10.13031/trans.12128

Trayford, R. S., \& Welch, L. W. (1977). Aerial spraying: A simulation of factors influencing the distribution and recovery of liquid droplets. J. Agric. Eng. Res., 22(2), 183-196. https://doi.org/10.1016/0021-8634(77)90062-2

WHO. (2011). Guidelines for drinking water quality (4th ed.). Geneva, Switzerland: World Health Organization.

Wong, S.-C., \& Chang, J.-C. (1992). Evaporation of non-dilute and dilute monodisperse droplet clouds. Intl. J. Heat Mass Transfer, $35(10), 2403-2411$. 